\title{
Power Above and Below the Waterline: Bridging Political Economy and Power Analysis*
}

\author{
Jethro Pettit and Andrés Mejía Acosta
}

\begin{abstract}
The power relations that underlie poverty and exclusion can make or break development programmes, if not understood and addressed at all stages of design and implementation. Political economy and power analysis represent distinct but complementary approaches to making sense of power in the context of development initiatives. Both approaches are used to provide organisations with a better understanding of key actors and their interests, and of the enabling and constraining structures, conditions and narratives in which their actions take place. These include both observable and less visible norms, institutions and discourses, and the formal and informal motivations shaping different actors' behaviour in supporting or blocking change. This article seeks to clarify the similarities and differences between political economy and power analysis, what they each can offer, and how they may be used in complementary ways to make development cooperation more effective and transformative.
\end{abstract}

\section{Introduction}

Methods of political economy and power analysis are increasingly used by development organisations which recognise the importance of understanding context, actors and relationships. Gaining a practical grasp of power and political economy in the contexts where they work, it is hoped, will help them to better plan, strategise, identify entry points, map actors, foresee pitfalls and opportunities, and ultimately lead to improved policy outcomes. This interest in power and political economy has generated demand for useful concepts, methods and tools of analysis. Donor approaches can be said to fall into two very broad categories: 'power analysis' and 'political economy analysis', which offer distinctive but also complementary ways of understanding how power operates. Understandably, there is confusion as to what is meant by 'power' and 'political economy' - whether they are the same thing, whether they complement or contradict one another, and which is best suited for particular issues or contexts.

This article seeks to clarify these two broad approaches and to identify their similarities and differences. We maintain that while they are ontologically distinct (i.e. based on different meaning systems), they can be used in complementary ways. However, their different starting points make it important to surface their assumptions about how change happens, rather than simply 'mixing methods'. We identify what each approach can and can't offer, and argue that when used together they can question taken-forgranted development narratives. We also suggest that it is useful to ask who should do power or political economy analysis, when and why.

\section{Power and political economy analysis compared}

Interest in power and political economy analysis has grown as development donors and civil society actors recognise the effects power relations can have on their policies and programmes, and the benefits of solid context analysis. While often referred to in the same breath, power and political economy approaches have different ontological, epistemological and disciplinary groundings. As 'power' has been famously described as an 'essentially contested' concept (Lukes 2005), it is no surprise that these approaches view power from different positions. Simply put, political economy analysis explains the behaviour of political actions through the 
Figure 1 Power and political economy analysis: looking above and below the waterline

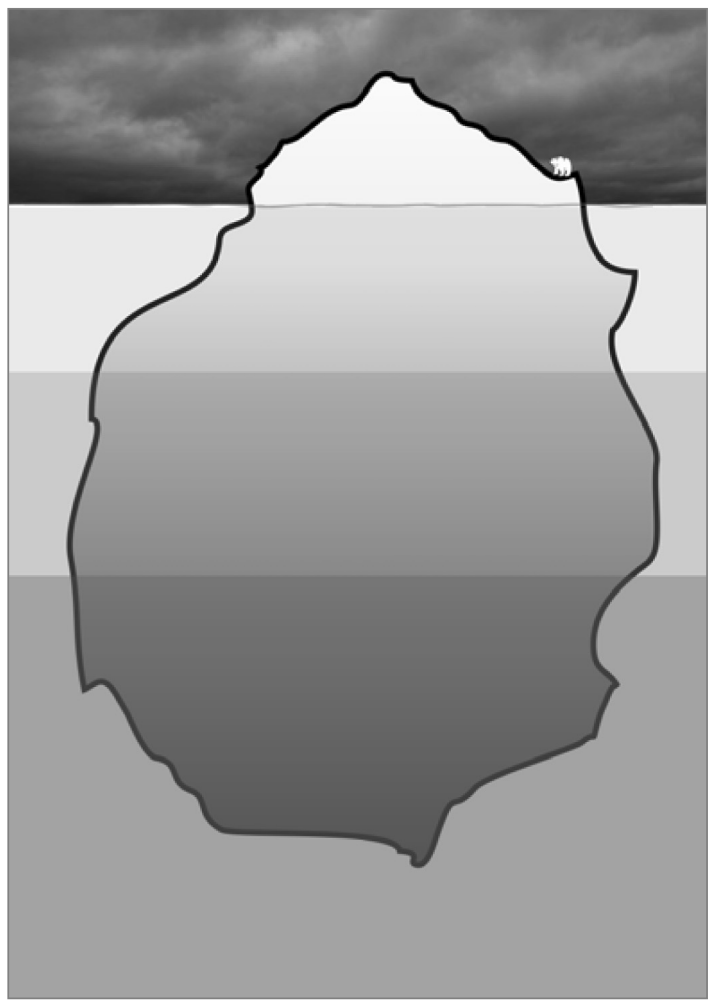

Illustration by Shabnam Akram.

lenses of economic institutionalism - applying economic assumptions about human behaviour and rational choice to political and institutional behaviour and relationships. The main focus is on identifying key actors, their assumed or observed interests, and what helps or hinders their cooperation. Structures, norms and 'rules of the game' that shape their behaviour are also considered. In contrast, power analysis is informed by critical theory, anthropology, political sociology and feminist theory. It gives greater attention to the influence of socialised and internalised norms on behaviour, and to the interplay between agency and structure. Both approaches, in different ways, seek to unpack the more and less visible dimensions of power and relationships that facilitate or block change.

The image of an iceberg is a useful analogy for what these two traditions offer, and where they overlap and complement one another (Figure 1). Political economy tends to focus on actors, structures and processes that are visible and 'above the waterline', as well as what may lie half-hidden under the surface such as informal norms, institutions and relationships. Power analysis is concerned with less visible social norms, beliefs and structures well 'below the water line', as well as half-hidden patterns near the surface that shape actors' behaviour and relationships. By combining these perspectives, we can gain a more complete and systemic view of how power operates across the spectrum of these different levels. This, we argue, can provide a more robust analysis that surfaces assumptions, exposing blind spots and unquestioned narratives. But to do this, we need to understand these different lenses, and what they do and don't perceive.

\section{What is political economy analysis?}

Political economy analysis (PEA) is broadly defined as a 'methodology of economics applied to the analysis of political behaviour and institutions' (Weingast and Wittman 2006). This broad definition includes both a set of concepts and frameworks that looks at the intersection between economics and politics as a unique field of study (Barnett, Hinich and Schofield 1993), but also as a methodology that uses economic institutionalism as well as historical and institutional analysis to understand political dynamics (Alt and Shepsle 1990; North 1990).

The contemporary use of PEA can be traced back to the 1950s when political scientists systematically used instruments of economic analysis to better understand political cooperation dilemmas, the competition for electoral votes, the distribution of scarce resources, the advancement of political careers, and the formation of coalitions, to cite a few examples (Arrow 1951; Downs 1957; Riker 1962; Mayhew 1974; Ostrom 1990). After the 1990s, the next generation of PEA significantly revolutionised the understanding of political dynamics, especially to understand legislative politics, budget politics, electoral dynamics, the bureaucracy, the judiciary, fiscal and monetary policies, international relations, ethnic conflict, decentralisation, democratisation, and so forth (Barnett et al. 1993; Weingast and Wittman 2006).

PEA permeated the thinking and practice of many bilateral and multilateral development agencies as early as the 1990s (Burki and Perry 1998). Several agencies including the Department for International Development (DFID), GIZ, USAID 
and parts of the UN followed suit in subsequent years with different tools and instruments to understand 'Poverty and Social Impact Analysis', 'Problem-Driven Governance and Political Economy Analysis', 'drivers of change' or 'political settlements' (Booth et al. 2005; DahlOstergaard et al. 2005; Booth et al. 2006; Di John and Putzel 2009; Leftwick 2010; Khan 2012; Routley and Hulme 2013). Although the detail and methodology has varied, the primary focus of PEA is on actors, networks, institutions and their competing interests. PEA can incorporate varying levels of analysis - macro (country context), meso (policy implementation) and micro (policy impact) (Haider and Rao 2010: 4); and be done with different audiences in mind, including rigorous academic assessments, country practice guides and rapid assessments (Reich and Balarajan 2012).

\subsection{Common features of political economy analysis}

A complete survey of the common elements and methodologies that define PEA is not possible here. However, some of the underlying features include:

Institutions matter. There is an explicit recognition that norms and structures matter to shape individual behaviour and indirectly development (policy) outcomes (North 1990). Institutions are taken as given 'rules of the game' that set out the context, motivations and sanctions in which strategic individuals make choices. While early versions of PEA focused on given formal governance and economic structures, contemporary approaches consider:

a how both formal and informal institutions are embedded in social and historical contexts that shape behaviour (Levitsky and Helmke 2004);

b how institutions tend to reproduce power asymmetries, as they reflect the preferences and interests of influential actors (Moe 2005);

c institutional strength and resilience (Levitsky and Murillo 2009).

Individuals matter. For the most part, PEA tends to focus on individuals or agents as the main unit of analysis (i.e. mayors, presidents, bureaucrats, citizens). An underlying premise is that political behaviour tends to reflect for the most part, the best interests of such individuals, given their legal, economic and social constraints; however, there are some important revisions to keep in mind:

a The best interest of individuals does not only include material benefits or rewards. The search for the common good or even altruistic behaviour can be modelled as furthering the best interest of an individual;

b The notion of best interest will change with context and over time; for example, individuals tend to have different attitudes towards taking risks when they are relatively wealthier than when they are poorer (Bernstein 1996);

c Actors are not always individuals but sometimes they represent a collection of likeminded individuals with similar interests (i.e. a political party or an association of municipalities, or institutional interests such as the military).

Commitment matters. Political economy analyses pay special attention to understanding the motivations of individuals to cooperate (or not) over time. A critical part of reinforcing commitment is the role of 'third party enforcers', to help cement agreements, legitimise decisions, and uphold (enforce) agreements (Scartascini $e t$ al. 2008).

a These commitment devices can take the form of actors, rules or 'currencies' (i.e. money, prestige, material goods);

b These enforcers could be reflected in a formal institution (e.g. the judiciary or a Supreme Court) or an 'informal' institution (e.g. a council of tribal chiefs).

\subsection{Advantages and limitations of political economy analysis}

The main advantage of using PEA in a development setting is that it seeks to understand the behaviour of key actors not in a moral, normative or ideal fashion but rather in terms of strategic responses to existing norms and structures. For example, the act of paying a bribe in exchange for a service may be a survival response in a culture of corruption and deficient government services. Another advantage is the explicit recognition of the intersecting space between the formal rules of the game and the informal 
practices of actors on the ground. Furthermore, PEA could be used to understand the political institutions and dynamics operating at different stages of the policy process (formulation, approval, implementation, monitoring) to identify entry points for donor intervention. For example, citizen participation efforts are usually geared towards helping policy formulation or monitoring execution, but rarely for overseeing the process of legislative adoption.

There are some limitations of PEA that need to be taken into account. First, a political economy analysis will be of limited use unless there is an articulation of a specific theory of change associated with the expected development initiative. In other words, it would be difficult to identify the main actors, institutions and drivers of change unless there is an explicit discussion of how change takes place and why and when this is more likely to happen. It is useful to ask, for example, 'Why should politicians care about child malnutrition?' 'Who are local politicians accountable to?' 'Why - and when - do people mobilise to demand regime change?' Note that PEA does not tend to ask how institutions or norms change - rather who will support or oppose these reforms and who the 'drivers' are likely to be.

A second limitation is that PEAs require a significant degree of background work and adaptation to the specific context if the analysis is to produce useful insights into the relevant actors, norms and dynamics. Usually sector-specific PEAs can yield important information about the politics behind a concrete development initiative, but this would in turn need to be informed by a national level analysis of political dynamics. For example, a PEA of water management can look at the relevant actors and networks around the local provision of safe and clean water, but it will need to be complemented or informed by the dynamics and motivations to deliver public services of the main political parties at the national level.

In addition to the significant time of analysis and level of expertise, a comprehensive PEA needs constant updating to reflect changing factors in the development context. The specific validity and practical relevance of a PEA depends on how the analysis is able to incorporate changes due to external shocks (i.e. natural disasters and emergency situations), domestic factors (i.e. after elections) or international factors (i.e. changes in donors' spending priorities). While a PEA will not be able to anticipate these factors or their consequences, it should provide the analytical elements so that development practitioners can adjust the main findings of PEA according to new developments. For example, the validity of a PEA explaining the politics of effective and transparent service delivery in municipal governments may change after holding local elections; in this case, the motivations and priorities of some elected mayors may change, but the imperative for improved service delivery, the institutions of municipal decentralisation and the available fiscal resources will remain the same.

\section{What is power analysis?}

Power analysis (PA) is a general term used to describe the approaches used by development and social change actors to better understand the ways in which different dimensions of power act to reinforce or reduce poverty and marginalisation and to identify actors, entry points and positive forms of power that can be mobilised in favour of desired changes. Power analysis has multidisciplinary roots, drawing broadly on the fields of social theory, politics, political sociology, anthropology and feminist theory. It complements the strong actor- and organisation-orientation of PEA by giving greater attention to the role of socialised and structural dimensions of power, how these may enable and constrain actors, and how they change. PA is a method of context analysis that articulates a theory of change and identifies strategies that may be effective; it has mostly been used to develop a country strategy or design a programme or sector strategy, but has also been used in mid-term reviews, evaluations and learning processes. ${ }^{1}$

\subsection{Common features of power analysis}

Power analysis draws on a range of concepts and frameworks that explore both the formal and observable, and the informal and less visible dimensions of power. A commonly used framework is the notion that power may take 'visible', 'hidden' or 'invisible' forms (VeneKlasen and Miller 2002; Gaventa 2006), building on the concept of 'three dimensional power' (Lukes 2005). This framework distinguishes between the formal and observable exercise of power (visible), power or bias that is exercised from behind the scenes (hidden), and hegemonic norms and beliefs that secure consent to domination (invisible). 
Power is often understood simplistically as 'power over' - forms of authority, control or domination. This may take the form of brute domination, but it can also operate by constraining what others think they can do or even imagine is possible. 'Power over', like 'invisible power', extends beyond physical or verbal forms of domination to affecting the ways in which people view themselves and their rights and capabilities.

For example, Gramsci's hegemony describes how people are persuaded to do things that are against their own best interests (Gramsci 1971). They come to accept the claims of elites that the pursuit of their own interests coincides with a general interest. Ideals and norms are 'hegemonic' if they hold people in their sway, remain unquestioned and come to be viewed as 'common sense'. Gender analysis offers a similar framing of power: the idea that women cannot do certain jobs because of physical inadequacies or that women make better parents than men has been hegemonic at certain points in history, and in certain contexts. PA draws on frameworks of empowerment to identify the positive 'expressions of power' that may be needed to counter hegemony, such as the idea that less powerful people can develop 'power to, power with and power within' (Rowlands 1997;

VeneKlasen and Miller 2002):

- 'Power to' is agency or the ability to act and can begin with the awareness that it is possible to act; it can grow in the process of taking action and realising that one can effect change, as well as through developing skills and capacities.

- 'Power with' describes collective action, and includes both the psychological and physical power that comes from being united and acting together to resist domination.

- 'Power within' describes the sense of confidence, dignity and self-esteem that comes from gaining awareness of one's situation and realising the possibility to do something about it.

These 'expressions of power' or agency are reminders that power can be used positively as well as negatively, by the disempowered as well as the powerful. The concepts are often used together: people need 'power within' in order to act, and 'power to' to act collectively; the 'power with' of shared understanding and action can also strengthen self-esteem and agency (Veneklasen and Miller 2002).

\subsection{Advantages and limitations of power analysis}

Advantages. Learning about power, and analysing context and interventions with a power lens can help development actors develop sensitivities and competencies that enable them to act in ways that will shift these relations and to empower marginalised people. Like PEA, power analysis is used to deepen contextual and structural understandings of the national and regional situations in which an organisation works, as well as the global actors and forces that influence this local context. Its value added is to identify enablers and constraints related to people's aspirations and cultural norms that may affect an intervention - for example, creating participatory spaces may not work if people cannot imagine having control over their lives. Programme staff and partners can use power analysis to anticipate responses and prevent their programmes from being blocked or co-opted by powerful interests, and to identify entry points they may not have considered.

Power analysis can also identify possible perverse consequences, as when poverty reduction or postconflict reconstruction programmes empower wealthy people or warlord factions, rather than people living in poverty. Power analysis can be a means of building the knowledge and competencies needed by staff and partners to work effectively within complex, unequal and fast-changing environments. Power analysis can also help those working in development to reflect on their own positions as political actors, both personally and institutionally, and to become more aware of how to handle the power dynamics of their relationships. This dimension is often missing from context analysis.

Limitations. Power analysis does require a certain level of understanding of and ability to apply key concepts of structure and agency, which typically reach beyond the quick identification of actors, their interests and networks. It can require some time and practice to use, and if staff or consultants are not familiar with them, they may be used in more superficial and limited ways. The emphasis on sociological and ideological context and structure can also divert attention away from the practical analysis of actors, their interests and relationships - 'losing sight of the wood for the trees'. For this reason we find it practical to emphasise the complementarity between different approaches. 


\begin{tabular}{|c|c|c|c|}
\hline & Political economy & $\leftarrow \rightarrow$ & Power analysis \\
\hline Main dimensions of power & Visible & Hidden & Invisible \\
\hline $\begin{array}{l}\text { The role of institutions/ } \\
\text { rules of the game }\end{array}$ & $\begin{array}{l}\text { For the most part, } \\
\text { institutions are taken as } \\
\text { given or they are hard to } \\
\text { change in the short run }\end{array}$ & $\begin{array}{l}\text { Emphasis on informal } \\
\text { institutions, often resilient } \\
\text { to change }\end{array}$ & $\begin{array}{l}\text { Focus on 'structuration' - } \\
\text { interplay between conscious } \\
\text { agency and internalisation of } \\
\text { norms }\end{array}$ \\
\hline Examples of institutions & $\begin{array}{l}\text { Formal government and } \\
\text { NG institutions (mayors, } \\
\text { cabinets, NGOs); existing } \\
\text { norms and regulations }\end{array}$ & $\begin{array}{l}\text { Informal institutions } \\
\text { (traditional governance } \\
\text { structures, militias) }\end{array}$ & $\begin{array}{l}\text { Social institutions (gender } \\
\text { norms, ethnic identity, etc.) } \\
\text { and networks (kinship, } \\
\text { political solidarity) }\end{array}$ \\
\hline The role of individuals & $\begin{array}{l}\text { Individual, rational action. } \\
\text { Organisational action }\end{array}$ & $\begin{array}{l}\text { Combine individual and } \\
\text { collective actions through } \\
\text { networks }\end{array}$ & $\begin{array}{l}\text { Focus on individual and } \\
\text { collective consciousness } \\
\text { (shaped by different factors) }\end{array}$ \\
\hline $\begin{array}{l}\text { Cooperation and } \\
\text { contestation }\end{array}$ & $\begin{array}{l}\text { Collective action is the } \\
\text { result of individual } \\
\text { motivations }\end{array}$ & $\begin{array}{l}\text { Collective action results } \\
\text { from individual motivations } \\
\text { and social norms }\end{array}$ & $\begin{array}{l}\text { Collective action results } \\
\text { from social and cultural } \\
\text { norms }\end{array}$ \\
\hline Sanctions and enforcement & $\begin{array}{l}\text { Formal (legal) ways to } \\
\text { legitimise agreements } \\
\text { (contracts) or sanction } \\
\text { defections }\end{array}$ & $\begin{array}{l}\text { Informal sanctions outside } \\
\text { formal legal norms, such } \\
\text { as bribery or coercion }\end{array}$ & $\begin{array}{l}\text { Fear of exclusion or loss of } \\
\text { identity; internalised social } \\
\text { norms }\end{array}$ \\
\hline $\begin{array}{l}\text { How they explain change } \\
\text { over time (key drivers of } \\
\text { change) }\end{array}$ & $\begin{array}{l}\text { Types of actors, } \\
\text { preferences and strategies } \\
\text { change but institutional } \\
\text { change is much slower } \\
\text { ('Change from above'?) }\end{array}$ & $\begin{array}{l}\text { Greater trust in agency to } \\
\text { change power relations. } \\
\text { ('Change from below'?) }\end{array}$ & $\begin{array}{l}\text { Changes in critical awareness } \\
\text { and sense of empowerment } \\
\text { leading to growth in agency } \\
\text { ('Change from within'?) }\end{array}$ \\
\hline $\begin{array}{l}\text { Example: how to ensure } \\
\text { effective service delivery } \\
\text { from local governments? }\end{array}$ & $\begin{array}{l}\text { What are the legal, } \\
\text { political, and financial } \\
\text { resources allocated to } \\
\text { local governments? }\end{array}$ & $\begin{array}{l}\text { Who performs local } \\
\text { government functions in } \\
\text { practice? Power operates } \\
\text { 'behind the scenes' }\end{array}$ & $\begin{array}{l}\text { Who is neglected from } \\
\text { local governments or does } \\
\text { not benefit from delivery of } \\
\text { services, and why? }\end{array}$ \\
\hline $\begin{array}{l}\text { Sample recommendations } \\
\text { emerging from analysis }\end{array}$ & $\begin{array}{l}\text { Influence policymaking } \\
\text { through political advocacy } \\
\text { and seeking access to } \\
\text { formal decision-making }\end{array}$ & $\begin{array}{l}\text { Strengthen and empower } \\
\text { organisations, build } \\
\text { collective leadership, raise } \\
\text { the visibility of issues, } \\
\text { mobilise new voices }\end{array}$ & $\begin{array}{l}\text { Raise consciousness to } \\
\text { transform the way people } \\
\text { perceive themselves and } \\
\text { those around them }\end{array}$ \\
\hline
\end{tabular}

Note NG = national government.

Source Authors' own.

\section{Political economy and power analysis combined}

Power and political economy analysis both seek to explain how some individuals or groups behave towards and seek to control others, how consent to such control is secured and maintained, and what enables or prevents actors from cooperating with one another. An agency perspective sees power as something that people and institutions can hold, wield, lose and gain, usually through political or military alliances or contestations. It is concerned with the interests and motivations of actors, and drives their ways of relating to one another. A structure perspective sees power as the social and cultural norms and beliefs that are unconsciously internalised and that shape, often invisibly, people's thoughts and actions. Power is embedded in all relationships, institutions and systems of knowledge, and is part of the way our societies and cultures work. These understandings of power often form the basis of a theory of society, which looks not only at actors and relationships but at how social 
norms and structures are created, reproduced and transformed.

A useful entry point for combining the analysis of power, particularly in political decision-making and democratic participation, is to look at three 'dimensions' or 'faces' of power (Lukes 2005; Gaventa 2006; VeneKlasen and Miller 2002). As noted above, the typology moves from the visible power of formal decision-making processes, to the hidden power of organised biases and agendasetting behind the scenes, to the invisible power of forces that shape people's consciousness and felt needs.

In practice, the three types of power will overlap. However, it is important to combine the visible and hidden or informal dimensions of power with the underlying cultural and social norms and practices in order to identify how development changes take place. Table 1 offers a systematic guide to compare how the political economy and power analysis frameworks can better understand the different dimensions of power.

\subsection{The common features of political economy and power analysis}

It is useful to disaggregate the key elements of political economy and power analysis, in order to see what each perspective contributes to understanding them. Here we consider four key elements that shape power relations, but there are certainly others:

- Formal and visible structures, institutions and rules of the game;

- Informal and invisible structures, norms, beliefs and narratives;

- Actors, their interests and strategies;

- Processes of cooperation and contestation.

For each element of analysis we describe what aspects are considered by political economy or power analysis, and suggest some guiding questions to further explore these complex manifestations of power in an applied setting.

\section{Structures, institutions and rules of the game}

Formal power can be thought of as the visible, recognised structures of power that are part of the way in which societies work: institutions that mediate the relationship between those with legitimate authority and those who are subject to that authority, the laws and rules that define what is acceptable and what is not acceptable, and how those who break laws and flout norms are treated. There are several decades of work around institutional analysis looking at (a) 'how institutions work'; (b) the expected behavioural effects and resulting outcomes; and (c) sources of endogenous change (who shapes those institutions in the first place?). Over the past two decades, there has been renewed attention at the less visible or legally recognised ways through which norms, rules and behaviour are regulated, sometimes through informal, illegal or clandestine forms of coercion. Taken together, this set of institutions form part of 'the rules of the game', or the set of clearly defined norms and rules that are accepted, communicated and enforced through formal and informal channels.

The notion of 'the rules of the game' closely defines the arenas or spaces in which power and political dynamics take place. Conversely, it could be said that power relations in different arenas are shaped by different rules of the game. A powercube framework has been developed to analyse the ownership and inclusiveness of different spaces of public deliberation and decision-making (Gaventa 2006). ${ }^{2}$ According to the framework, decision-making can take place in closed, invited or claimed spaces. Spaces are closed when they limit the opportunities for inclusion outside established procedures (e.g. council member meetings include members previously elected for that role but not others). Spaces are invited when citizens can permeate decision-making bodies to voice their concerns (e.g.public consultations); such spaces are usually established by authorities for citizen participation. Finally, spaces are created or claimed when actors create alternative arenas for engagement and action (e.g. alliances, street protests). By looking at different arenas and the rules that shape them, the analysis can identify 'political opportunity structures' or entry points to effectively influence decision-making.

Importantly, the notion of spaces looks beyond actors and their assumed interests and relative power, and considers the ways in which power may operate in these points of interaction. The power relations between actors will be shaped by the rules and norms (visible, hidden and invisible) that determine access to spaces, accepted ways of behaving and speaking within them, and how agenda-setting and decision- 
making are governed. Spaces underscore the extent to which power is fluid, temporal and contextual rather than fixed.

Key questions are:

- What are the formal existing institutions (legal frameworks, norms, regulations) defining the rules of the game?

- Are these rules stable over time or predictable?

- Are they legitimised or widely accepted?

- Are they effectively applied? If not, why?

What are the existing practices that define how the game is actually played?

- Do these rules seek to expand, complement, or contradict the existing formal rules of the game?

- Are these rules stable over time or predictable?

- Are they legitimised or widely accepted?

- Are they effectively applied? If not, why?

- Who participated in drafting the rules of the game? At what point in time were these rules decided?

- Do the rules represent the views, values or interests of a particular group?

\section{Invisible norms, discourses and narratives}

Informal power can be thought of as the socialised norms, discourses and cultural practices that are part of our everyday lives. Informal power relations are internalised through socialisation from a young age, starting with acceptance of inequality in roles, for instance, between father and mother and older and younger family members, or boys and girls. These informal power relations are often taken for granted as given, or natural. Because deliberate strategies of coercion or domination are not required, informal power is sometimes also referred to as 'invisible' power (VeneKlasen and Miller 2002; Gaventa 2006) or the 'third dimension' of power (Lukes 2005). The distinction between formal and informal power is useful in drawing attention to the fact that changes in formal and visible structures or strategies of domination are necessary, but not sufficient to transform societies and make them more equitable. Laws may precede and indeed hasten social change, but to be effective they need to be accompanied by efforts to change socialised norms, attitudes and values.
Much social theory focuses on these less visible and culturally embedded forms of power to explain how social norms, hierarchies and patterns of behaviour are automatically reproduced and resistant to change. Some focus on the deliberate strategies and actions of powerful actors to manipulate the consciousness and felt needs of less powerful actors (e.g. Lukes 2005). Others explain this not as a result of intentional 'agency' or even of deterministic 'structures', but as a kind of continuous and unconscious interplay between agency and structure - where power is understood as the norms, discourses and behaviour that are socialised and internalised by all actors (e.g. Bourdieu 1980; Foucault 1991; Hayward 2000).

Key questions are:

- What are the predominant identities? - How are these identities shaped and reproduced by social and cultural norms? - How do they influence political and judicial structures and processes?

- How do people's self-perceptions of their identities either reinforce or challenge prevailing social and cultural norms? - How do these identities shape different values or discourses?

How are different narratives built into common development discourses?

- Do these discourses contribute to reinforcing social hierarchies or exclusion? - How do these narratives build on beliefs, norms and cultural practices to legitimise and reinforce material power structures?

- Are these narratives used to advance reforms or legitimise the status quo?

\section{Actors, interests and strategies}

Both political economy and power analysis recognise the role of agency in producing policy changes, and the fact that these actors are bound or limited by existing formal or informal power relations. The focus on actors seeks to identify whether the relevant players have the capacity to produce meaningful development changes. Strictly speaking, however, it is important to distinguish who are the critical or veto players without whom policy changes could not take place, and the other players who are important but not decisive for producing changes. A second important distinction is that the relevant veto 
players are not always visible or fully mobilised that are nevertheless present in the development process. Finally, critical actors tend to be identified with individuals or organisations (presidents, mayors, municipalities, NGOs). However in practice, it is relevant to disaggregate who the critical actors are, and whether it is safe to assume that a collective body (e.g. municipality) is represented by a single actor (e.g. the mayor) or whether there is greater complexity within (e.g. a diverse group of municipal council members).

Once the key development actors have been identified, the next step is to establish what are their powers, roles and responsibilities. Again, their role may already be defined by the formal and legal institutions or structures (e.g. a mayor), or by traditional norms (a council chief). Yet this description should be different from analysing the actual motivations and interests to fulfil their expected roles, independent of their formal obligations (e.g. a mayor may be directly accountable to his/her party leaders, rather than the will of the voters).

In sum, some of the relevant questions to keep in mind when analysing actors and interests are:

- Who are the main actors involved?

- Who is decisive to produce development changes?

- Who is present but not decisive?

- Who is decisive but not present or (not yet) mobilised?

What are the prerogatives, attributions, responsibilities of these actors?

- Who established these roles?

What are the motivations of these actors to fulfil their responsibilities?

- What are their preferences, interests, strategies?

- What do they really do in practice?

\section{Cooperation and contestation}

The question of what makes actors cooperate with one another or not, is probably one of the most decisive pieces of the analysis to understand what kind of development changes can take place. Yet an answer to this question cannot be fully articulated until there is clarity on the formal and informal rules, and the interests and motivations of actors. Over time, political science has invested heavily in understanding the logic of collective action. Simply put, joint or cooperative action is likely to take place when: (a) there are fewer individuals (who can keep track of one another's actions); (b) individuals have converging interests along the same dimension or issue; (c) individuals tend to share longer time horizons; and (d) there are credible enforcement mechanisms to ensure cooperation. By contrast, it follows that larger groups of individuals with diverse interests or backgrounds, who have short-term interests and mistrust one another are unlikely to produce cooperation.

Needless to say, not all forms of cooperation are formalised, long-term or ideological. It is often the case that temporary alliances (or alignments of interests) take place around specific agreements at one given point in time. It is also the case that different clusters of actors can form rotating or changing coalitions. These are all valid forms of cooperation, they are unlikely to lead to sustained or even continuous development changes over time.

Some of the relevant questions to keep in mind when analysing actors and interests are:

What are the actors' motivations to cooperate with one another?

- Is it duty, tradition, self-interest?

- Is it short-term or long-term interest?

What makes cooperation possible?

- Is it formal agreements, informal pacts or material exchanges?

- Do existing institutions facilitate cooperation?

How do actors ensure cooperation?

- What happens if/when actors abandon their agreements?

- Are there any explicit rules, formal agreements or informal pacts to ensure cooperation?

\section{Application: developing a shared theory of change}

One of the most common questions that comes up when applying political economy, power analysis, or a mix of the two, is how can these make a difference in practice? There is no 
shortage of analyses that had no impact whatsoever on design and implementation, let alone monitoring and evaluation, although more research is needed to document this empirically (Routley and Hulme 2013). There are also strong institutional inertias within donor agencies that make it difficult to accept and act upon PEA recommendations to implement effective reforms on the field (ibid.). From a country office perspective, the challenge is to avoid the cost of hiring regular consultants to update or develop sector-specific PEAs for every new intervention.

One concrete way forward is for country offices to develop a common understanding of a programme's theory of change, given the existing stakeholders, motivations, institutions and limitations highlighted by the country's PEA. The idea is to develop a political baseline that explains how power and power relations operate in a given policy sector, who are the main allies and opponents to a proposed policy change, what are the potential coalitions for change, and most important of all, to develop a clear idea of what effective and practical policy change would look like. Based on this shared understanding of power dynamics, the country office's staff should be able to develop accurate objectives, strategies, entry points, activities, outcomes and indicators that respond to the analysis.

We suggest that in many cases a combined political economy and power analysis will lead to a more robust, multi-perspective theory of change. By looking at power from different angles and assumptions, making these viewpoints explicit and comparing them, the analysis will be more likely to identify decisive actors, rules and underlying social dynamics. It should then be possible to articulate an explicit understanding of (a) the goals or objectives of a specific development initiative, and (b) the causal and contextual factors that are most conducive to achieving that goal. Recent studies and systematic reviews around transparency and accountability initiatives have found that there is little or no in-depth analysis of what 'meaningful change' looks like in this development field (Gaventa and McGee 2013). A related concern is the lack of a 'theory based' approach to project development and evaluation that explains 'the implicit assumptions, logic and mechanisms behind complex development interventions [...] contribut[ing] to a better understanding of the causal/impact chains' (Gaventa and McGee 2013; White 2010). This section addresses both issues.

\subsection{Identifying the notion of 'success'}

The use of political economy and power analysis is likely to yield accurate policy recommendations if there is a clear and practical definition of the expected outcome of a development initiative. If we take for example current initiatives around accountability and transparency, it becomes clear that a simple definition of 'success' is obscured by the confusion of whether transparency and accountability are 'means to an end' or 'ends' in themselves (Mejía Acosta 2013; Gaventa and McGee 2013). In the first case, existing development interventions could be more explicit about what the expected impact of 'accountability' is supposed to achieve, namely improved service delivery or increased citizen participation. But if 'improved citizen participation' appears as an expected outcome, it would be useful to theorise and explain key questions such as 'which citizens it refers to', whether they were 'active prior to the creation of the mechanism', 'where they get their information', 'how they act upon it', 'on which issues they mobilise', and 'whether they are wellbehaved or antagonistic toward state institutions', to cite a few (McGee and Gaventa 2011). An indepth understanding of what constitutes a 'successful' development initiative is a key step for identifying the sequence of factors leading to that goal.

Sometimes, development initiatives are correct in pursuing a higher-end and explicit long-term development goal, but failed to make explicit the immediate short-term changes needed to achieve longer-term impact. Even in these cases, an explicit discussion of the proximate or intermediate objectives would be useful to identify an operational notion of 'meaningful change', as well as the sequence of necessary steps leading to it.

\subsection{How does change happen?}

A key feature of political economy and power analysis, combined, is that it offers a systematic way for understanding the key stakeholders, norms, discourses and power dynamics contributing to (or continuously blocking) the attainment of meaningful change. Assuming there is a clearly defined notion of meaningful change such as the improvement in the delivery of public services, the specialised literature tends to assume a causal connection that begins with 
citizens' awareness (i.e. to improved information), towards articulating citizens' voice (i.e. through formal and informal institutions), and increasing the responsiveness of service providers (i.e. establishing clear sanctions when public servants fail to do their job) (Joshi 2013). While the causal link between accountability and improved service delivery may be intuitive to development practitioners, 'this chain of causation is seldom explicitly examined' in existing development initiatives aimed at increasing transparency and amplifying voice (McGee and Gaventa 2011).

A first step towards identifying how change happens would entail an identification of the key decisive actors or veto players (whose consent is needed to adopt new policy changes), the commonly shared interests and motivations, and the existing institutions, norms and arenas that facilitate these changes (Tsebelis 2001). In this context, identifying the relevant 'drivers of change' and the corresponding coalitions for change constitute key steps to understanding how meaningful changes can take place.

But identifying an expected - even if preliminary - theory of change, could also be useful to understand why change does not happen or why changes are systematically blocked and by whom. Rarely in development, and in public policy in general, do policy changes take place in a linear, incremental way. More often, political economy and power analysis can be used to explain why development changes have not taken place or why the motivations of actors do not change over time. Depending on the case, key actors would have incentives to block reforms if these go against their vested interests. In practical terms, a systematic stakeholder mapping of drivers and blockers, enablers and spoilers, would allow the identification of 'bottlenecks' in the reform process, that is, critical situations or arenas where there is no visible agreement and a policy stalemate ensues; another example is the presence of 'glass ceilings' or stages in the reform process beyond which any meaningful change is no longer possible due to the presence of vested interests. Equally, the analysis may show how accepted social norms and behaviours perpetuate the problems despite successes in the policy sphere - pointing to the need for other kinds of initiatives, such as working with the media, culture or social movements.
In sum, we argue that existing development initiatives for the most part are not underpinned by a clear articulation of exactly what outcome or impact is sought, or of how the actions and inputs contemplated are expected to generate that outcome or impact (McGee and Gaventa 2011). A combined political economy and power analysis can help to surface and sharpen this vision. The following guiding questions seek to address that gap and help practitioners to identify key elements in the process of change.

Key questions are:

When and how is change likely to happen (or not)? - Who are the critical actors needed to produce meaningful changes?

- Are there any actors not present or that could be mobilised more effectively?

- What are the possible coalitions of change?

What holds these coalitions together?

- What are the arenas, norms and structures enabling (or blocking change)?

- What are the 'bottlenecks' to reform? What are the glass ceilings?

\subsection{Entry points for cooperation}

If properly done, a combined political economy and power analysis framework, or a menu of approaches drawing from both traditions, would help development practitioners to identify the national level and sector-specific context in which proposed interventions are likely to work. The analysis should also help identify the decisive actors for producing meaningful change as well as those blocking it, to articulate more clearly what the possible coalitions for reform are. It would also identify the informal and invisible power dynamics that block change, or that could be mobilised to enable change. But perhaps most important of all, the combined framework or menu would offer an analytical map of the sector or domain to inform the discussion (amongst development actors) of where lie the key entry points for a successful cooperation and where the perceived risks are.

A useful consideration in this regard, for example, is to distinguish whether the same actors play different roles and have different entry points in the policy process to facilitate or block meaningful change. Taking for example the role of municipal mayors in participatory budgeting, it is often assumed that local 
authorities can greatly benefit from enhancing citizens' participation in budget formulation. However, a broader discussion of relevant actors and dynamics throughout the budget process will show that mayors lack the technical competencies to demand scarce government funds from the central government, including the Executive and the Ministry of Finance. In this example, any cooperation funding to support participatory budgeting will be incomplete unless the motivations, capabilities and political alignments of mayors vis-à-vis the central government are taken into account.

Some guiding questions from the combined framework include:

What would a 'successful' donor or organisational strategy or programme look like? - Who are the key actors that can maximise initiatives? Which actors could potentially block the desired change?

- Who are the key actors that have not yet been identified, mobilised or could be better supported?

- What are the assumed spaces of interaction, and could more be done to create new spaces, formal or informal, or to change the culture of existing spaces?

Where and when are the opportunities for change and reform?

- At which point in the policy process can meaningful change take place? What are the entry points and sequences of intervention that may be needed?

- What complementary strategies may be required, beyond the conventional ones (e.g. to address visible, hidden and invisible power)?

- Are staff and partners well prepared to support meaningful change (financially, technically, politically)?

\section{Ways forward for a combined approach}

The combined or complementary approach to political economy and power analysis is an effort to combine different analytical and methodological traditions to better understand political and power dynamics facilitating or blocking development interventions. The very act of combining and comparing different standpoints on power and political economy can lead to a more robust and explicit analysis.
There are several ways in which this work can be and will be strengthened in the near future.

Conceptually, we need to further refine and combine the different frameworks to identify the ways in which alternative, context-relevant development narratives can be created and embedded around particular interventions to boost or hinder prevailing development discourses. Importantly, there is a need to recognise the inherent tensions as well as complementarities: political economy and power analysis are rooted in different disciplines, with distinct ontological and epistemological underpinnings that are not always compatible. Applied alone, each tradition is likely to neglect certain dimensions of power; and combined too simplistically, there are risks that important concepts will be only partially understood or weakly applied within the framing of a single set of assumptions. Inter-disciplinary work is essential in this regard.

Empirically, we need to further develop survey, interview, observation and other instruments to adequately capture, in quantitative and qualitative terms, the different actors, interests, norms, institutions and change coalitions. We will continue to develop practical tools and frameworks for applying these concepts in complementary ways within cooperation processes (many do exist and are being tested with SDC, Sida and other organisations). An important lesson emerging from such efforts is that the concepts, lenses and tools of political economy and power analysis can best be integrated in a selective way into existing processes and instruments, rather than burdening overworked staff with yet another requirement. The analysis can be applied in light and insightful ways at all stages of a cooperation cycle, rather than as a single ex ante exercise; more work, for example, is needed to integrate political economy and power analysis into evaluation and outcome measurement (McGee and Pettit 2013).

Practically, there is a need to work collaboratively to develop training and capacity development resources and sessions to teach and validate these approaches working closely with diverse organisations and at different levels. For example, more efforts could be made to integrate power analysis frameworks and tools into political economy training and guidelines, 
and vice versa. There is also a need to develop more participatory and multi-stakeholder approaches which can allow partner organisations to develop shared analyses, theories of change, strategies, and evaluation frameworks which consider the multiple, context-specific dimensions of power. Further

\section{Notes}

* This article builds on IDS collaboration with the Swedish International Development Cooperation Agency (Sida) to develop guidelines for power analysis (Pettit 2013) and with the Swiss Agency for Development and Cooperation (SDC) to strengthen power and political economy analysis within the programmes of its Decentralisation and Local Governance Network (DLGN) (Mejía Acosta and Pettit 2013). This article is adapted with permission from these two publications, and support from colleagues at SDC and Sida is gratefully acknowledged. Thanks also to Shandana Mohmand, Alex Shankland and participants in political economy and power

\section{References}

Alt, J.E. and Shepsle, K.A. (1990) Perspectives on Positive Political Economy, Cambridge: Cambridge University Press

Arrow, K.J. (1951) Social Choice and Individual Values, New York: John Wiley

Barnett, W.A.; Hinich, M.J. and Schofield, N.J. (1993) Political Economy: Institutions, Competition, and Representation, Cambridge: Cambridge University Press

Bernstein, P. (1996) Against the Gods: The Remarkable Story of Risk, New York: John Wiley

Booth, D.; Cammack, D.; Harrigan, K.; Kanyongolo, E.; Mataure, M. and Ngwira, N. (2006) Drivers of Change and Development in Malawi, Working Paper 261, London: Overseas Development Institute (ODI)

Booth, D.; Crook, R.; Gyimah-Boadi, E.; Killick, T. and Luckham, R. with Boateng, N. (2005) What Are the Drivers of Change in Ghana?, Policy Brief 1, London: Overseas Development Institute (ODI)

Bourdieu, P. (1980) The Logic of Practice, Stanford: Stanford University Press

Burki, S.J. and Perry, G.E. (1998) Beyond the Washington Consensus: Institutions Matter, Washington DC: World Bank

Dahl-Ostergaard, T.; Unsworth, S.; Robinson, M. and Jensen, R.I. (2005) Lessons Learned on the involvement could include programme-specific accompaniment, action learning, assessments and practical capacity development workshops with organisations and their partners. Applied, experiential learning approaches can be a vital complement to more formal training.

analysis workshops held in Brighton, Bern, Sarajevo, Stockholm, Prishtina and Skopje from 2012-14. Surbhi Mahajan and Katy Oswald provided valuable research assistance.

1 IDS has been documenting and innovating with various methods of power analysis over the past decade through its work with Sida (e.g. Pettit 2013), SDC (this article), DFID and a number of international NGOs and civil society organisations worldwide. In the UK this work has been developed into practical methodological guidelines for use by grassroots organisations (Hunjan and Pettit 2011; Pettit 2013).

2 See also www.powercube.net.

\section{Use of Power and Drivers of Change Analyses in Development Co-operation, Paris: OECD-DAC GOVNET}

Di John, J. and Putzel, J. (2009) Political Settlements, Issues Paper, Governance and Social Development Resource Centre, http://epapers.bham.ac.uk/645/1/EIRS7.pdf (accessed 13 June 2014)

Downs, A. (1957) 'An Economic Theory of Political Action in a Democracy', Political Economy 65.2: 135-50

Foucault, M. (1991) Discipline and Punish: The Birth of a Prison, London: Penguin

Gaventa, J. (2006) 'Finding the Spaces for Change: A Power Analysis', IDS Bulletin 37.5: 23-33

Gaventa, J. and McGee, R. (2013) 'The Impact of Transparency and Accountability Initiatives', Development Policy Review 31, Issue Suppl. S1: s3-s28

Gramsci, A. (1971) Selections from the Prison Notebooks of Antonio Gramsci, New York: International Publishers

Haider, H. and Rao, S. (2010) Political and Social Analysis for Development Policy and Practice: An Overview of Five Approaches, Birmingham: Governance and Social Development Resource Centre, commissioned by AusAID Hayward, C. (2000) De-facing Power, Cambridge: Cambridge University Press 
Helmke, Gretchen and Levitsky, Steven (eds) (2006) Informal Institutions and Democracy: Lessons from Latin America, Baltimore: Johns Hopkins University Press

Hunjan, R. and Pettit, J.G. (2011) Power: A Practical Guide to Facilitating Social Change, Dunfermline: Carnegie UK Trust Joshi, Anuradha (2013) 'Do They Work? Assessing the Impact of Transparency and Accountability Initiatives in Service Delivery', Development Policy Review 31: s29-s48

Khan, M. (2012) 'The Political Economy of Inclusive Growth', in Luiz de Mello and Mark A. Dutz (eds), Promoting Inclusive Growth: Challenges and Policies, OECD Publishing

Leftwich, A. (2010) 'Beyond Institutions: Rethinking the Role of Leaders, Elites, and Coalitions in the Institutional Formation of Developmental States and Strategies', Forum for Development Studies 37.1: 93-111

Levitsky, S. and Helmke, G. (2004) 'Informal Institutions and Comparative Politics: A Research Agenda', Perspectives on Politics 1.4: 725-40

Levitsky, S. and Murillo, M.V. (2009) 'Variation in Institutional Strength', Annual Review of Political Science 12: 115-33

Lukes, S. (2005) Power: A Radical View, 2nd ed., London: Macmillan

Mayhew, D.R. (1974) Congress: The Electoral Connection, New Haven: Yale University Press

McGee, R. and Gaventa, J. (2011) Shifting Power? Assessing the Impact of Transparency and Accountability Initiatives, Brighton: IDS

McGee, R. and Pettit, J. (2013) Outcome Measurement in Local Governance Programmes: A Power Dimension, Work in Progress Paper, SDCDLGN, Brighton: IDS

Mejía Acosta, A. (2013) 'The Impact and Effectiveness of Accountability and Transparency Initiatives: The Governance of Natural Resources', Development Policy Review 31, Suppl. S1: s89-s 105

Mejía Acosta, A. and Pettit, J. (2013) Practice Guide: A Combined Approach to Political Economy and Power Analysis, Work in Progress Paper, SDC-DLGN, Brighton: IDS
Moe, Terry M. (2005) 'Power and Political Institutions', Perspectives on Politics 3.2: 215-33

North, Douglas (1990) Institutions, Institutional Change and Economic Performance, Cambridge: Cambridge University Press

Ostrom, E. (1990) Governing the Commons: The Evolution of Institutions for Collective Action, Cambridge: Cambridge University Press

Pettit, J. (2013) Power Analysis: A Practical Guide, Stockholm: Swedish International Development Cooperation Agency (Sida)

Reich, M. and Balarajan Y. (2012) Political Economy Analysis for Food and Nutrition Security, HNP Discussion Paper 76921, Washington DC: World Bank

Riker, W.H. (1962) The Theory of Political Coalitions, New Haven and London: Yale University Press

Routley, L. and Hulme, D. (2013) Donors, Development Agencies, and the Use of Political Economy Analysis: Getting to Grips with the Politics of Development, ESID Working Paper 19, Manchester: Effective States and Inclusive Development Research Centre (ESID), University of Manchester

Rowlands, J. (1997) Questioning Empowerment: Working with Women in Honduras, Oxford: Oxfam Publications

Scartascini, C.; Spiller, P.; Stein, E. and Tommasi, M. (2008) Policymaking in Latin America. How Politics Shape Policies, Inter-American Development Bank, Harvard University Press

Tsebelis, G. (2001) Veto Players. How Political Institutions Work, Princeton NJ: Princeton University Press

VeneKlasen, L. and Miller, V. (2002) A New Weave of Power, People and Politics: The Action Guide for Advocacy and Gitizen Participation, Oklahoma City: World Neighbors

Weingast, B.R. and Wittman, D. (eds) (2006) The Oxford Handbook of Political Economy, Oxford: Oxford University Press

White, H. (2010) 'A Contribution to Current Debates in Impact Evaluation', Evaluation 16.2: $153-64$ 